\title{
SLUM HOUSING: A FUNCTIONAL ANALYSIS
}

\author{
George SternLieb*
}

\section{INTRODUCTION}

A sharp division is opening in the ranks of American social activists between the institutionalists and what may be termed the "marketers." The axiomatic role of present housing policy as a social input similarly is under challenge. Congress reflects this uncertainty on optimum action for the future.

The institutionalists are those individuals who, harking back to the lesson of the r930s, believe in the disposition of social welfare funds through channels clearly defined and structured by the government. There is a strong acceptance by them of certain given tools and values: external guidance of the poor reflected in strong advocacy of public housing, efforts to strengthen the ministrations of the welfare worker, and so on.

The marketers, at least in the socially activist area, are much newer and harder to describe. Essentially they are united in believing that the poor should have greater options-for example, that social welfare funds should be utilized directly to enhance the buying power of the underprivileged, without an intervening structuring of the disposition of these funds. The use of guaranteed incomes in some form is a frequently advocated instrument. Inadequacies of housing are seen as reconcilable by giving the poor more money-and permitting them at their option to buy better shelter.

Obviously, the dichotomy indicated above does not do justice to the broad range of in-between belief, of tools such as rent subsidies which are usable by either group, and of the diversity of consumers to be serviced by the low-end housing market. Accepting these strictures, however, I am still impressed by the speed with which the concept of bringing the poor into the market mechanisms, as against direct governmental servicing of their needs, has progressed.

In substantial part this change in attitude mirrors the change in the perspective given the problems of the poor. A very short time ago, for example, the expression "urban problems" would have been used in place of "problems of the poor." In part this would have been a euphemism-in part, however, it mirrored the confusion in thinking and motivation prevalent at the time.

There has been a confusion between efforts at rehabilitating the city on the one hand, and helping people who happen to be presently concentrated within cities, on the other.

*A.B. 1950, Brooklyn College; M.B.A. 1953, D.B.A. 1962, Harvard University. Professor, Graduate School of Business Administration, Rutgers-The State University. Author, THE FUTURE OF THE Downtown Department Store (1962); The Tenement Landlord (ig66); Social Needs and Social ReSOURCES $(1967)$. 
I

\section{The Negro in the City}

\section{A. "If There Were No Negroes"}

"If there were no Negroes, the city would be ...." Any of a number of "good" things are proposed by all too many people of the United States as a function of this introductory clause. The sins of the city: its decay, its lack of relevance to the current folkways of middle class America, and not infrequently all of its problems generally, are seen as a function of the change in the racial mixture which has taken place in this last generation. I would suggest that this is romantic hogwash. The city is an antiquated form of social organization; its social and economic relevance to the growth frontiers of American society are and have been increasingly tenuous over a lengthy period of years.

The inadequacies of municipal government, revealed strikingly by the series of riots which seems to be a commonplace of every summer, are neither new nor unique. It is not that municipal government is less adequate; to the contrary, a good case can be made for its being much more adequate than was true historically. It is rather that the realities of the city simply cannot provide the standard of living and amenities which the new focal points of American civilization-the new cities, the suburbs-hold out as a measuring stick of adequacy.

\section{B. Black Power Romanticism}

The efforts of Black Power advocates, in this context, can similarly be seen as completely anachronistic in aspiration; the city which they attempt to secure is a bankrupt entity. It is bankrupt not merely in answers, but in its capacity to deliver the improved standard of living which is the universal of American middle class aspiration levels. The "trauma" of the city have been with us probably since its inception.

The city is falling into discard, not because its population distribution has been altered, but rather because the world around the city, the competition faced by the city as an organization, has changed. It is competition, rather than decline in the absolute level of service, that has altered its role. Any efforts at changing this situation must take this basic premise into account. Unfortunately, this has not been the case. Past governmental policy in the city was substantially one, at least initially, of rebuilding some conceived of Golden Age in the past.

The city must be made a way station toward middle class America for the new immigrants, just as it was for older groups. It is as a means to an end that the city and its housing is to be utilized, rather than as an end in itself.

\footnotetext{
${ }^{2}$ A clear case in point is the effort to secure Negro ownership of the traditional central core small stores in the face of the discount house and supermarket.
} 
Using THE SLUMS

The very slums of the city provide a potential takeoff place in this regard, if we can move toward owner residence. This can provide a key element in the development of capital accumulation for the core dweller.

If a gross oversimplification may be permitted, the problem of the slums is one both of plumbing and morale. It has largely been viewed in the past as consisting solely of the plumbing. This is not to denigrate the latter; the provision of appropriate housing amenities is certainly an essential step toward improving the outlook and aspiration level of slum dwellers. However, the morale problem cannot be cured merely by providing these physical amenities.

The present market situation is one of virtual stagnation in the hard core slum areas. The combination of risk, decreasing profitability, and loss of potential for capital gains has substantially restricted the kinds of professional owners who are willing to invest in slum properties. It takes a pretty hard-shelled individual to become a professional nonresident owner of slum property, given present societal attitude. And this is not an individual who is easily influenced to invest his money unless an appropriate return can be secured. Given the relative weakness of the slum apartment market, the professional landlord has been faced with the choice of basically two alternatives: to stand pat and not increase his investment, or to attempt to improve his parcel in order to secure higher rentals.

The pattern that we have seen in our studies indicates that the choice has usually been the former. The observer cannot fail to be struck by the "heads we win, tails you lose" nature of this phenomenon. When the apartment market is very strong the landlord need not improve; when the apartment market is very weak the landlord fears for his investment and does not improve. ${ }^{2}$

\section{III}

What Is, or Should Be, Public Policy Toward Slums and Slum Dwellers?

The goal of government policy towards the slums must have as its primary aim the improvement of the morale of the inhabitants thereof: tax policy, code enforcement policy, financing aid, municipal service policy, all of these must be viewed within the context of the overall objective.

The community must face the realities of the slum situation fairly, without self-deception or romanticism, and at the same time move for change. Let us review the slum conditions as they exist.

I. In Northern industrial cities, the overwhelming majority of hard core slum

"See generally G. Sternzieb, The Tenement Landlord (1966); J. Meyer, H. Schwartz et al., Economic Description of the Real Estate Market on the Lower East Side of New York (ig67). 
area residents are Negroes. The decreasing number of whites are typically an elderly remnant of earlier immigrations.

2. There is little evidence of a substantial return of the white middle class to the slum areas of the city.

3. The bulk of slum tenements are owned by absentee white owners. These owners are not merely absentee from the slums per se, they are also absentee, at least as residents, from the city in which they own property.

4. The single most basic variable which accounts for variations in the maintenance of slum properties is the factor of ownership. Good parcel maintenance typically is a function of resident ownership.

5. Subject to major programs of land clearance for the purposes of urban renewal or highway construction or both, a population vacuum is developing in the slums. The tidal wave of southern Negro migration, has slowed down and is substantially bypassing some of the northern cities which were its traditional goal. With a virtual stability in Puerto Rican migrant population size, there is no new depressed group on the horizon to fill the older slums.

6. While this population decrease makes the problem of relocation much simpler, it also tends to limit the landlords' capacity and will to improve parcels.

7. Given a substantial dependence upon land taxes in the face of increased demands upon the municipality for services, taxes have become a major inhibitor of entrepreneurial activity in the central city. Particularly in terms of the uncertainty which surround their administration, current municipal tax policies are leading to further degeneration of the slums.

8. The relationship of client and patron, which plays a dominant role in the dealings between government, both municipal and federal, and the poor population of the slums, is deleterious to the morale of the individuals concerned.

IV

Boosting the Proportion of Resident Landiords in Slum Tenements

There is no question of the significance of local landlord residence, particularly of single parcel landlords, in ensuring proper maintenance of slum tenements. Given the priority accorded by multiple-parcel owners to tenant problems and the lack of feeling on this score by resident landlords, ${ }^{3}$ the latter's good record in maintenance is most significant. It is the resident landlord, and only the resident landlord, who is in a position to properly screen and supervise his tenantry. No oneshot wave of maintenance and a paint-up, sweep-up campaign, can provide the day-to-day maintenance which is required in slum areas. This can only be accomplished by a resident landlord. The record of these landlords as we have noted in our studies is such as to inspire confidence in their future behavior on this score.

\footnotetext{
${ }^{3}$ When asked to rank his problems, the resident landlord cites tenants as minor. The absentec owner, however, puts tenant problems in first place.
} 
By making it feasible for more residents to become owners, we further encourage the development of local leadership which is so sorely lacking in most slums. The role of resident owners as guides and creators of life patterns for the youth of the slums to follow is clearly evident. Most important of all, we can encourage the growth of capital accumulation which is an essential of social mobility within our society.

\section{A. Financing}

How could this type of development be stimulated? There are several prime requirements. The first of these, obviously, is financing help. The term of mortgages is much more significant from a cash flow point-of-view than are interest rates. For example, a mortgage at six per cent which is written for a fifteen year period involves less cash flow than an equivalent size mortgage for a ten year period at $3^{1 / 2}$ per cent. Given the dearth of available financing which is currently the case in the slums, there is obviously no alternative but to provide something in the way of long-term FHA-guaranteed mortgages for slum tenement purchases by residents. The analogy with the early Homestead Act springs readily to mind. ${ }^{4}$ In that case government lands were provided to those who would live on them, at relatively reasonable rates and with liberal financing. The same thing must be done in the slums.

\section{B. Advisory Services}

Financing, however, is merely one of the several steps which is required. The relatively innocent new resident buyers of slum tenements are frequently victimized by a variety of home improvement services. Thus, a moneylender, interviewed by the writer, pointed to the fact that commonly, when he has to repossess a parcel, the typical cause is that the owner has burdened the parcel with two, three, or more home improvement loans. Just as the Agriculture Department provides a variety of advisory services for the farmer, so the city or the federal government, or both, must provide equivalent advisory services for the new home owner in the slum areas. These advisors must be competent not merely in home improvements, but also in financing and appraising parcels. It would seem entirely possible that among the ranks of senior savings and loan people, as well, possibly, as within the ranks of the present FHA personnel, such individuals could be found. Technical competence, however, must be linked with a basic sympathy with the aspiration level of the now owner and with none of the deux ex machina attitude that so often exists in government relations with the poor.

\section{Tax Policy}

The question of tax policy is a most significant one on this score, as it is with respect to the general problem of slums. It may well behoove the city to continue

\footnotetext{
'Ch. 75, 12 Stat. 392 (1862).
} 
its policy of full assessment based upon market values. Obviously, where broadbased taxation is available on a basis other than land, it may reduce some of the strain. Reassessment policy, however, must be more clearly defined than is presently the case. The landlord should have no reason to fear city reassessment as a result of a new coat of paint.

It is essential that the city not merely adopt a more reasonable attitude toward taxation, but also sell the facts of this attitude to those who may be influenced by misconceptions as to its reality. In addition, in the long run it may very well pay the city to provide the equivalent of homestead rebates for resident landlords. This is a format (which will be recognized by those who are familiar, for example, with tax policy in a city such as Miami Beach) in which the homesteader-i.e., the resident landlord-receives either a reduction or a rebate in his real estate taxes. This might well be coupled with a stipulation that the rebate be employed in the improvement of the parcel in question. The area of uncertainty and suspicion which surrounds current taxing procedures must be clarified. Its existence clearly inhibits improvements.

\section{Municipal Services}

There seems to be ample evidence that the level of municipal services required by the slum areas is higher than that required by nonslum equivalent areas. At the same time, there is reason to believe that the actual delivery level of these services is reversed, with poorer areas being slighted.

Every effort must be made by the city to provide an optimum level of services within the slums. Such functions as police protection, street lighting, parking restrictions, garbage collection, and a host of others could be named here. Not least among these is the question of educational facilities. While this is a subject whose depth is beyond the scope of this article, it can not be omitted. Without substantial efforts on all of these fronts, the efforts at utilizing the slum as ladders toward upward mobility will fail.

\section{E. Code Enforcement}

Parallel with all of the above suggestions is the requirement that code enforcement be made much more rigorous. But, prior to this, there is required a much more adequate definition of just what the code should be. Adequate insect and rodent control, plumbing that works, paint, and general cleanliness may be much more significant to the inhabitants of a tenement, both physically and spiritually, than the existence of central heat or plaster walls. Whether the studs used in a repair are sixteen inches on center or are twenty inches on center may be completely irrelevant to a tenant. A building which is completely satisfactory on the basis of existing codes may be completely unsatisfactory in terms of its effect upon its occupants. 
Code enforcement, therefore, must require a much more subjective approach than has heretofore been the case. This is particularly the case with those buildings in the hands of landlords who cannot afford repairs. In those cases, it may be necessary to work out a long term plan of rehabilitating the parcel in question-with major emphasis being given to the paint and cleanliness functions, those most easily encompassed by "sweat equity." Good maintenance and resident landlordism are much more significant than mechanical adherence to a mechanical code.

\section{V}

\section{The Future of the Hard Core Slum}

I would seriously question the potential of hard core slum areas for rehabilitation. Given the relatively loose housing market, which presently exists in many center cities, the bulldozer approach to such hard core areas would seem to be the only answer. This should not wait upon redevelopers. The existence of such hard core blight drags down the neighborhoods peripheral to it. ${ }^{\mathbf{5}}$

The loss of tax revenue to the municipality through this process of demolition must be accepted as surgery essential to preserve the surrounding areas from the spread of deep-seated blight. Obviously, the scale of this blight will require considerable discretion on the part of municipal authorities on the phasing and speed of demolition. Given the present functioning of the market, as has earlier been indicated, we cannot depend upon private enterprise to remove no longer useable buildings.

There is some question in my mind as to whether a change in tax policy to encourage demolition might not be in order. The city's need for more open space, and the potential of already assembled and cleared substantial size tracts in encouraging further development, must be depended upon to generate future use for the areas in question. Their maintenance by the city, given the facts of alternative housing availability, cannot be justified upon tax income reasons alone.

\section{VI}

\section{Conclusion: No False Romanticism}

The self-help capacity of the poor is limited. Some resident landlords are elderly, others are uneducated, and some lack an appropriate aspiration level. The fact remains, however, that as a group, they are presently the best landlords in the slums, and provide probably the major hope for better maintenance in the future. It will require a talented and understanding guidance operation to help generate landlord enthusiasm, while restraining over-expenditure. The problems here should

\footnotetext{
${ }^{5}$ Current gross vacancy rates, for example, in the twenty-five core census tracts of Newark are on the order of $10 \%$ in the midst of a tight housing market. This incongruity is a function of the lack of desirability of core vacancies. In the seventy-five tracts outside the core, the vacancy rate is under $4 \%$. G. Sternlieb et al., Vacancx Rate ANalysis (in preparation).
} 
not be underestimated. It is essential if this operation is to be truly successful, particularly from a morale standpoint, and also from the standpoint of securing long-run improvement, that the advisory service be a guide and an inspiration, not a directorate.

The present and future strains on the municipality's budget, coupled with limited increases in revenue, will make it most difficult to pay for the services that are required. The alternative, however, of increasing degeneration is all too clear-cut. From a fiscal point of view, the program outlined above is a most burdensome one; this point should not be evaded. There is no other answer, however, from the city's standpoint.

Tax policy must be directed toward aiding the good landlord and penalizing those owners who do not properly maintain their properties. A tax policy based on sales value can easily have the reverse effect. The potential of homestead exemption, of rigorous code enforcement, and of self-help stimulating devices must be rigorously exploited.

There is a well-founded fear on the part of the tenantry that rehabilitation leads to rent increases. This must be accepted as a fact of the market. Although tax policy can somewhat relieve this factor, particularly when coupled with more adequate financing, this fact should be faced. The potential of rent subsidies for the under-incomed, with which they can afford better rents, is clear-cut here. The reward in terms of the aspiration level and general morale of the slum dweller will, I think, outweigh the cost. This is particularly true when the cost/benefits are contrasted with those of institutionalized public housing.

The key to improving the slums from a "people" point of view is the creation of a resident responsible middle class within those areas-not a middle class which while physically in the area does not belong to it, as is the case with the efforts to create new middle class housing within slum areas cleared by urban renewal. This has no organic unity with the tenements per se and can only provide frustration, rather than leadership and emulation. These goals can best be accomplished and living conditions within the slum areas most enhanced, by increasing the number of owner residents of slum tenements. This will require a highly coordinated effort in terms of tax policy, financing help, code enforcement, and advisory services. The rewards of a successful program are very great. The cost of present policies are equally evident. 